\title{
RELATIONSHIPS BETWEEN THE BROOD STOCKS AGE AND SIZES (WEIGHT AND LENGTH)AND THE FIRST FISH MATURATION FOR BOTH MALES AND FEMALES OF GILTHEAD SEA BREAM, Sparus aurata (L.) \\ Abd El-Hakim, N. F. *; M. S. Hussein * and A. A. H. Shahen** \\ * Faculty of Agriculture, Al-Azhar University, Nasr City, Cairo, Egypt. \\ ** The General Authority for Fish Resources Development, Nasr City, Cairo, Egypt.
}

\section{ABSTRACT}

The objectives of this study aimed to evaluate the relationships between the brood stocks age and sizes (weight and length) and the first fish maturation for both males and females of gilthead sea bream , Sparus aurata (L,),

Five hundred juveniles sea bream(3month age) with average weight $4.6 \mathrm{~g}$ and length $5.9 \mathrm{~cm}$ were used in the present study through the period 2001 to 2004 (3years).

It could be concluded that the complete sexual maturity of male and female occurred at 36 month of age . The first maturation in females was recorded at 15 months of age, at weight $267.8 \mathrm{~g}$, length $22.4 \mathrm{~cm}$, and percentage $0.96 \%$ of the tested sample, while in males was recorded at 12 months with a ratio of $13 \%$ of the tested sample, weight was 73.4- 92.2gand length was $14.9-16.2 \mathrm{~cm}$. The complete sexual maturity of female occurred at 36 months of age at body weight ranging from 461.9 to $934.6 \mathrm{~g}$ and, which the total length was $30.3-42.4 \mathrm{~cm}$,but in males at the same age and average body weights ranging from 340 to $669.4 \mathrm{~g}$ with length $29.5-34.6 \mathrm{~cm}$. The sea bream male and female fish reached $100 \%$ maturation with a sex ratio $1: 1.38$ for female and male, respectively.

Keywords: Brood stocks age and sizes, first fish maturation, gilthead sea bream, Sparus aurata (L.).

\section{INTRODUCTION}

Gilthead sea bream (Sparus aurata) is amongst the most important fish species cultured in the Mediterranean region (Oliva,2000). Gilthead seabream (Sparus aurata) is one of the most important marine fish species for Mediterranean aquaculture. Gilthead seabream production reached up to 128.943 tonnes in 2008 with major suppliers from Greece (47\%), Turkey $(21 \%)$, Spain (19\%) and Italy (7.4\%) (FEAP, 2009). The demand and high value of this species led to farm this fishes under extensive condition in Egypt. The gilthead sea bream. Sparus aurata, has traditionally been considered as a high value fishery product of Mediterranean and Atlantic waters, with present annual landings of 3000-5000 ton The demand and high value of this species led to efforts to farm this fish under extensive system in Italy during the early part of the century (KirK, 1987). At present, gilthead sea bream is one of the major farmed fish in Mediterranean Europe. The gilthead seabream has traditionally been cultured in Mediterranean coastal lagoons and brackish/salt water ponds, especially in the northern Adriatic valli in Italy and the Egyptian hosha. These extensive fish rearing systems acted as like natural fish traps, taking advantage of the natural trophic migration of juveniles from the sea. Restocking was usually performed with wild fry and 
juveniles, collected by specialised fishermen. By the late 1970s, the reduced availability of wild fry and the increasing demand from intensive farms enhanced the development of induced spawning techniques, establishing by the end of the 1980s (Dimitriou,2000)).

In 2004, the world capture production of gilt head sea bream was of 8.914 tones, i.e. less than $10 \%$ of aquaculture production (FAO, 2006)).

The sea bream is a protandrous hermaphrodite: it is a functional male in the first two years and at over $30 \mathrm{~cm}$ in length becomes female. During the male phase, the bisexual gonad has functional testicular, with asynchronous spermatogenesis, and non functional ovarian areas (Zohar et al., 1978 and Zohar,1989). Ovarian development is also asynchronous, and females are batch spawners that can lay $20000-80000$ eggs per day for a period of up to 3 months. In the Mediterranean,they reproduce between October and December. The eggs are spherical and pelagic,with a diameter slightly lower than $1 \mathrm{~mm}$ and a single large oil droplet. The planktonic larval stage lasts about50days at $17-18^{\circ} \mathrm{C}$. (Boglione et al., 2003)

Large-scale cultivation of these species for human consumption demands when the resource be easily renewable. It is clearly disadvantageous to cultivate marine finfishes when the supply of young cannot easily be replenished; yet the history of aquaculture has been dogged by just this problem. There are two solutions to this problem: the first is eminently practical and has been the historical answer- to collect fry from natural resources. Yet, the difficulties inherent in this method are many, for it is time consuming, requires considerable skill and experience and relies utterly on the productivity of the natural spawning grounds. The second solution is more direct: learn how to make the brood stock marine finfishes reproduce in captive(Barnabe 1994$)$. The minimum length of ripe $S$. aurata males was $18 \mathrm{~cm}$, while that of female was $20 \mathrm{~cm}$. Fish larger than $21 \mathrm{~cm}$ for males and $23 \mathrm{~cm}$ for females were all mature. Therefore, the length at first maturity is $19-20 \mathrm{~cm}$ for males and $23 \mathrm{~cm}$ females. Another approach was tried to assess size at first maturation considering the work of Boglione et al., (2003) who has shown the presence of an all metric relation, in the covrse of growth between body weight of fish and that gonad. By plotting the log of gonadal weight per group weight, the straight line representing this relation is brocken at point corresponding to first body weight at the time of puberty (Boglione et al., 2003). Gilt-head sea bream is a protandrous hermaphroditic species (Zohar et al., 1978). In captivity, all fish function as males during the first year of their life. Under certain environmental conditions all fish remain males during their second year of life. From the first or second year onwards a certain percentage of the males undergo sex reversal, so that over succeeding years the ratio of females in the population increases (Zohar et al., 1978 and 1984). All females start to develop ovaries at the end of the spawning season (May). When their gonads become am bisexual, with the final commitment to changing sex into mature female made by September (Zohar et al.,1978). Males that enter into the am bisexual stage but ultimately do not become females, develop testes once more and become functional males again. Some studies showed that the proportion of males reversing sex is socially controlled (Zohar,1991).

Formatted: Font: (Default) Arial, $10 \mathrm{pt}$, Font color: Auto, Complex Script Font: Arial, $10 \mathrm{pt}$

Formatted: Font: (Default) Arial, $10 \mathrm{pt}$, Font color: Auto, Complex Script Font: Arial, 10 pt

Formatted: Font: (Default) Arial, $10 \mathrm{pt}$, Font color: Auto, Complex Script Font: Arial, 10 pt

Formatted: Font: (Default) Arial, $10 \mathrm{pt}$, Ital Font color: Auto, Complex Script Font: Arial, pt, Italic

Formatted: Font: (Default) Arial, $10 \mathrm{pt}$, Itali Font color: Auto, Complex Script Font: Arial, pt, Italic

Formatted: Font: (Default) Arial, $10 \mathrm{pt}$, Fon color: Auto, Complex Script Font: Arial, 10 pt

Formatted: Font: (Default) Arial, $10 \mathrm{pt}$, Fon color: Auto, Complex Script Font: Arial, 10 pt

Formatted: Font: (Default) Arial, $10 \mathrm{pt}$, Fon color: Auto, Complex Script Font: Arial, 10 pt

Formatted: Font: (Default) Arial, $10 \mathrm{pt}$, Font color: Auto, Complex Script Font: Arial, 10 pt

Formatted: Font: (Default) Arial, $10 \mathrm{pt}$, Fon color: Auto, Complex Script Font: Arial, 10 pt

Formatted: Font: (Default) Arial, $10 \mathrm{pt}$, Complex Script Font: Arial, 10 pt, (Complex) Arabic (Saudi Arabia)

Formatted: Font: (Default) Arial, $10 \mathrm{pt}$ Complex Script Font: Arial, 10 pt, (Complex) Arabic (Saudi Arabia)

Formatted: Font: (Default) Arial, $10 \mathrm{pt}$, Complex Script Font: Arial, 10 pt, (Complex) Arabic (Saudi Arabia)

Formatted: Font: (Default) Arial, $10 \mathrm{pt}$ Complex Script Font: Arial, 10 pt, (Complex) Arabic (Saudi Arabia) 
However, it is only during the period of May through September that the final sex of the am bisexual fish can be influenced by social and hormonal actors. Thus refer to this period as the sensitive period for sex determination. The presence or addition of young fish (Potential males) during the sensitive period increases the number of older fish that change sex into females. On the other hand the presence or addition of older female will inhibit sex reversal in younger fish and cause them to develop back into male (Zohar,1989).

The sex ratio is defined as number of males to females in the population (Andrades et al., 1994 and Boglione et al., 2003). On the other hand, the sex ratio was shifted to females at the length group of $25 \mathrm{~cm}$. The sex ratio was shifted to male at length group value ranged from 21 to 21.9 $\mathrm{cm}$. According to the sex ratio relative to length group, the sex ratio of female to male was $1.86 \%$. The ration showed that about 1.86 of female was needed for one male (Zaki et al.,1998). Sex was shifted to female at the length group of $24: 24.9 \mathrm{~cm}$. The sex ratio of female to male was $1.863: 1$.

The objectives of the present investigation were to carry out the relationships between the brood stocks age and sizes(weight and length)of gilt-head sea bream, Sparus aurata at first sexual maturity for both males and females, in the marine finfishes hatchery which belongs to the General Authority for Fish Resources and Development.

\section{MATERIALS AND METHODS}

The present study was conducted in Marine Finfishes Hatchery located at the $21 \mathrm{Km}$. west of Alexandcria, Matruh governorate. The hatchery belongs to the General Authority for Fish Resources Development (GAFRD), Ministry of Agriculture and Land Reclamation, ARE.

\section{Experimental Fish}

In this experiment a total number of 500 developed juveniles (males and females) gilt-head sea bream, Sparus aurata at ages of about 3 months, weighed at experimental start $4.6 \pm 206 \mathrm{~g}$ and a total length of $5.9 \pm 10.21 \mathrm{~cm}$ were stocked in a circular concrete tanks with a total water volume of $50 \mathrm{~m}^{3}$ sea water each. The experimental juveniles remain two years in these tanks, thereafter the experimental fish were transferred to a race-way rectangular concrete tank $(4 \times 20 \times 1 \mathrm{~m})$ with a total water volume of $80 \mathrm{~m}^{3}$ each during the last year of the experiment. This water of the experimental tanks was changed completely and the tanks were supplied with continuous air through a blower of $15 \mathrm{hp}$.capacity which provided $15 \mathrm{~m}^{3}$ air per second.. The sea bream juveniles used in this experiment were produced from the mating of parent stock of the hatchery. In this experiment, all fish were monthly transferred to another clean tank with the same specification to avoid infection with bacteria or parasites. 
Table (1): Ingredient and Proximate Composition of First experiment test diet used for gilthead sea bream, Sparus aurata juveniles from 12-36 months of age.

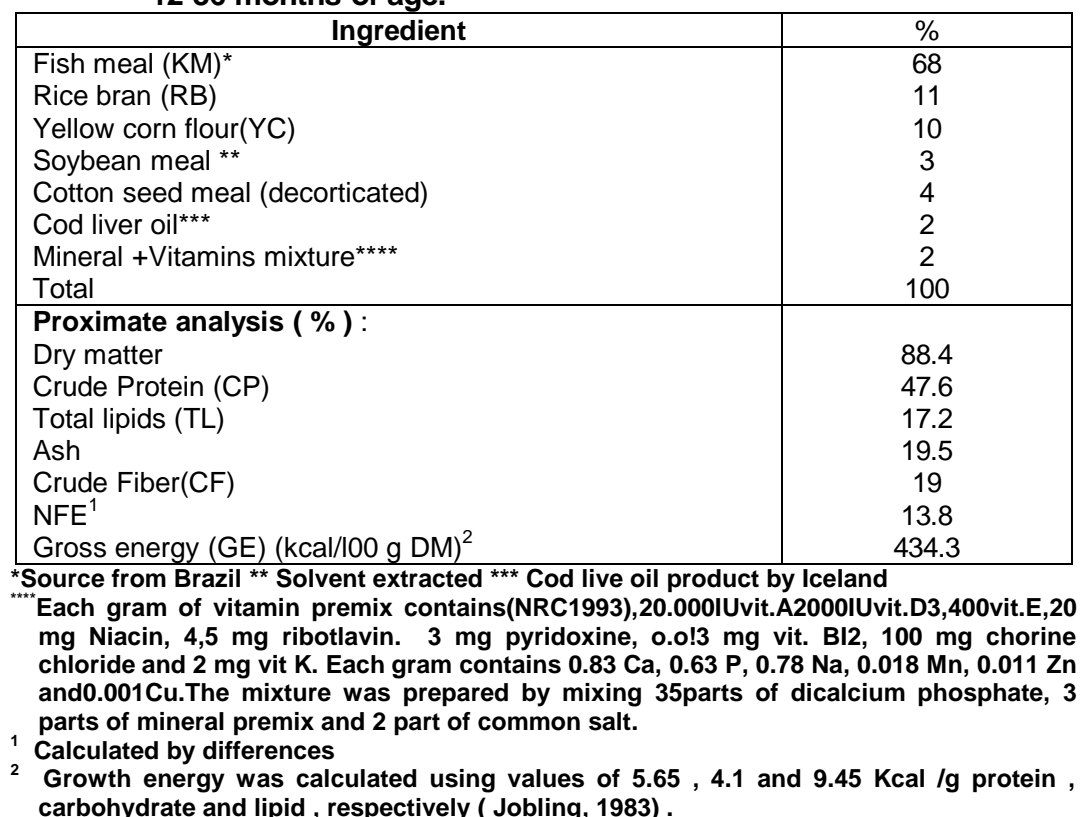

Table (2): Experimental periods, lasted for 5 consecutive periods for gilthead sea bream, Spams aurata juveniles rearing .

\begin{tabular}{|l|c|c|}
\hline Period & Age & Feed and rate for feeding \\
\hline Period. 1 & From 3-9 month & Minced tilapia $-12 \%$ \\
Period .2 & From 9-12 month & Minced tilapia- 10\% \\
Period. 3 & From 12-15month & Dry food-8\% \\
Period.4 & From 1 5-24 month & Dry food-6\% \\
Period.5 & Form 24-36 month & Dry food-3\% \\
\hline
\end{tabular}

\section{Experimental diet}

During this experiment, the experimental gilthead sea bream, Sparus aurata juveniles (mixed sexes) were daily fed during the first period (Table 3 ), from 3 to 9 months of age on minced tilapias bodies at a rate of $12 \%$ of the fish biomass. Whereas from 9 to 12 months of age $\left(2^{\text {nd }}\right.$ period) the experimental diet contained minced tilapias flesh daily rate of $10 \%$. of biomass . During this period 12 to 15 months experimental for gilt-head sea bream juveniles were fed on pelleted dry food $47.6 \%$ crude protein at a daily rate of $8 \%$ of biomass, and period from 15- 24 months of age feed the same test diet but at a daily rate of $6 \%$ of fish total biomass. From the 24 to 36 months of age the experimental fish were fed on the same diet, but at a daily rate of $3 \%$ of fish biomass (Table 1 and 2 ). 


\section{Sea water supply system:}

Sea water was drawn directly from an intake point in the shore by subs and well point (150 $\mu \mathrm{m}$ slots, 3pipes PVC, 3m length). Sea water was pumped by $4 \mathrm{~kW}$ polypropylene centrifuge pump to three concrete reservoirs of $60 \mathrm{~m}^{3}$ capacity, $13 \mathrm{~m}$ diameter $\times 1.5 \mathrm{~m}$ depth. The reservoir was used as a setting to the coarser suspended particles before the water was filtered. Water was pumped from reservoir to two constant head tanks $\left(5 \mathrm{~m}^{3}\right.$ capacity) to distribute for maturation and spawning tanks, and pumped to larval tanks.

\section{Drainage System:}

All the tank facilities were provided with two drainage system, one for cleaning water and other for removing water used in experimental fish rearing.

\section{Air Supply System:}

The air supply system consists of three air blowers work alternating at 24-hour interval.Air distribution network was constructed of PVC pipes and control valves.

\section{Measurements and Records}

Age of both males and females sea bass was recorded. Total weight and total length of each individual fish were recorded to the nearest $0.1 \mathrm{~g}$ and $1 \mathrm{~mm}$, respectively. Both weight and length of the experimental fish were recorded every 3 months till the end of the third year after experiment started. Age at sexual first maturity was determined by inserting a plastic cannula in the urino-genital opening to collect the eggs from the females, while semen was collected from males by stripping on the abdominal area towards tail fin.

\section{Water quality parameters}

Physical and chemical water parameters in experimental tanks were determined according to Boyd (1990). Water temperature in ${ }^{\circ} \mathrm{C}$ was daily recorded in all experimental tanks using a simple thermometer. Water $\mathrm{pH}$ was measured in the present experiment every week using a digital $\mathrm{pH}$ meter(model up Hep).Dissolved oxygen $\left(\mathrm{mg} \mathrm{O}_{2} / \mathrm{L}\right.$ )was monitored within all expcrimenlal tanks every week using a digital meter(YSI model MP57).Water salinity was determined in all experimental tanks at the periods previously mentioned in the experiment using a refractometer (model U-81150-20). Ammonia mg NH4-N/L) was determined using colormeter (Model HAC).

\section{Analytical feed methods :}

Feed ingredients and experimental diets were analysed for proximate composition according to AOAC(1990).

\section{Growth performance data}

Fish were counted and batch - weighed at stocking and at harvest. Mortality was monitored daily and survival was defined as the fraction of the stocked fish that were harvested.Average initial(Wi)and final fish body weight $\left(\mathrm{W}_{\mathrm{t}}\right)$ were calculated. Rearing time (t) was defined as the period from the first to the last day that the fish were fed.

Statistical analysis

Statistical analysis of the experimental results was conducted using SAS(2005)program. Duncan's multiple range test( 1955) was carried out to test the significance among intervals means $(\mathrm{P}<0.05)$. 


\section{RESULTS AND DISCUSSION}

Growth rate in weight $(\mathrm{g})$ and length $(\mathrm{cm})$ as well as percentage maturity was monitored for sea bream $S$. aurat raised in concrete tanks at 3 month intervals up to the 3-year of life. Results of Table (3) and Fig 1,2,3,4,5 and 6 showed the effect of age; body length and weight on sexual maturity of female and male of sea bream. Results revealed that in both sexs averages of body weight increased significantly $(P<0.05)$ with each advance in age from the age of 6 month till the age of 36 month, however differences in body weight between ages 3 and 6 months were insignificant. Results of Table 3 and Fig. 1 indicate that sea bream (male and female) average of BW at the experimental start (3months of age) was $4.6 \mathrm{~g}$ and it increased in order with each advance in age to reach $601.7 \mathrm{~g}$ at 36 month increased its BW by 130.8 $\mathrm{g}$ folds during the period from the third to the 36- months of age in both sexs. Results of the same Table indicate that the correlation coefficient $(r=0.9)$ between age and body weight was found to be highly significant $(P<0.05)$.

Table (3): Effect of age, body weight and total length on percentage maturation of gilthead sea bream, Sparus aurata

\begin{tabular}{|c|c|c|c|}
\hline \begin{tabular}{|ll} 
Age Month & Variable \\
\end{tabular} & $\begin{array}{l}\text { Weight g } \\
\text { Mean } \pm \text { sd }\end{array}$ & $\begin{array}{l}\text { Length cm } \\
\text { Mean } \pm \text { sd }\end{array}$ & $\begin{array}{l}\% \text { Mature } \\
\text { Mean } \pm \text { sd }\end{array}$ \\
\hline 3 & $4.6^{n} \pm 1.34$ & $5.9^{\prime} \pm 1.09$ & $0^{e} \pm 0$ \\
\hline 6 & $12.6^{\mathrm{h}} \pm 2.3$ & $8.4^{\mathrm{h}} \pm 0.9$ & $0^{\mathrm{e}} \pm 0$ \\
\hline 9 & $31.15^{\mathrm{g}} \pm 3.9$ & $13.05^{9} \pm 0.8$ & $0^{\mathrm{e}} \pm 0$ \\
\hline 12 & $95.045^{\dagger} \pm 12.9$ & $16.2^{\dagger} \pm 0.9$ & $17.3^{\mathrm{d}} \pm 0.38$ \\
\hline 15 & $172.8^{e} \pm 29.1$ & $19.6^{e} \pm 0.96$ & $18.2^{\mathrm{d}} \pm 0.38$ \\
\hline 18 & $294.3^{\mathrm{d}} \pm 54.7$ & $24.1^{\mathrm{d}} \pm 1.22$ & $25.3 c \pm 0.43$ \\
\hline 21 & $409.4^{c} \pm 103.9$ & $28.6^{C} \pm 1.19$ & $75.5^{b} \pm 0.43$ \\
\hline 24 & $542.1^{\mathrm{b}} \pm 122.2$ & $29.7^{b} \pm 1.39$ & $79.3^{b} \pm 0.4$ \\
\hline 36 & $601.7^{a} \pm 174.3$ & $33.15^{\mathrm{a}} \pm 3.5$ & $100^{a} \pm 0$ \\
\hline L.S.D. & 17. 9 sig. ${ }^{* \star *}$ & 0.3 sig. $^{* \star \star}$ & 0.06 sig. ${ }^{\star \star \star}$ \\
\hline
\end{tabular}

* Means with the same litters in the same row are not significantly difference $(P<0.05)$

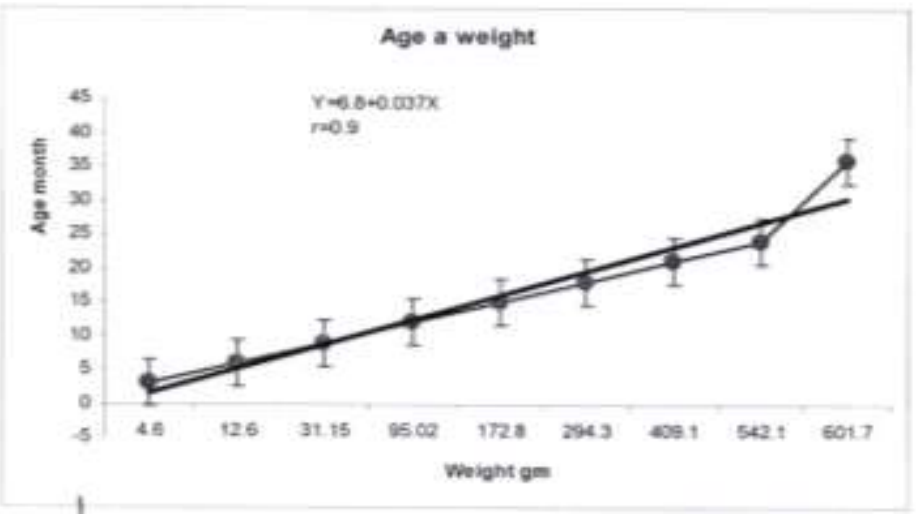

Fig. (1): The relation between weight(g)and age(months)of gilthead sea bream. Spaus aurata 
During the period from 3 to 36 months of age, the relationship between age and weight of male and female sea bream is illustrated in the following equation. $Y-6.8+0.03 \mathrm{X}$, where $\mathrm{y}=$ age in month and $\mathrm{X}=$ weight in Concerning body length (male and female) of sea bream, average of body length $\mathrm{BL}$ at the experimental start (3 months of age) was $5.9 \mathrm{~cm}$ and it increased in a significant $(P<0.05)$ order with each advance in age to reach $33.15 \mathrm{~cm}$ at 36 months of age which indicate that sea bream (males and female)grow 5.6 folds at 36 months of age compared to its length at 3 months of age (Table 3 and Fig. 2)

The calculated regression coefficient between age and length during the period of study ( 3 to 36 months of age) was $r=0.9$ and the statistical evaluation showed that the correlation (age / length) was highly significant and the relation between age and length is illustrated in the following equation , $Y=-3.2+0.09 X$, where $Y$ is age in month, and $X$ is length in $\mathrm{cm}$

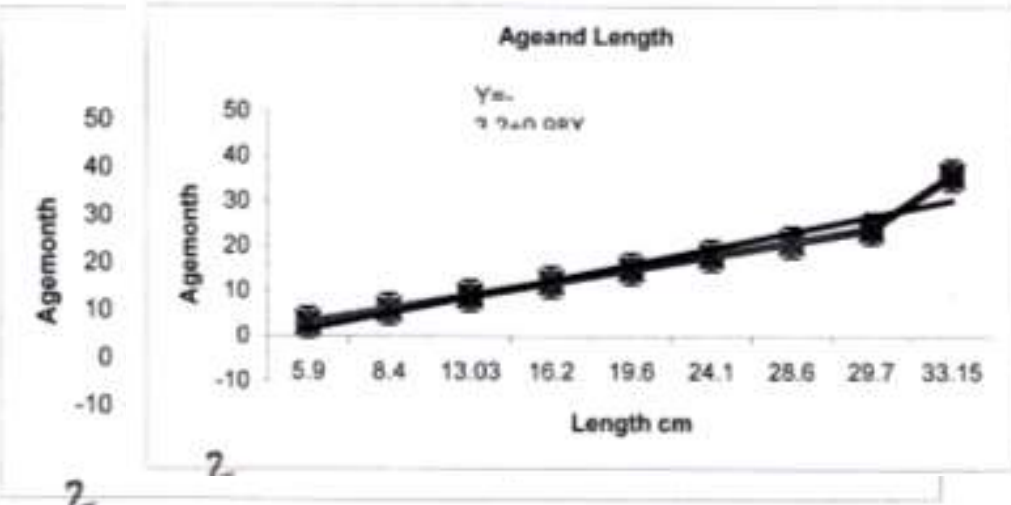

Fig. (2): The relation between length(cm)and age(months)of gilthead sea bream, Sparus aurata

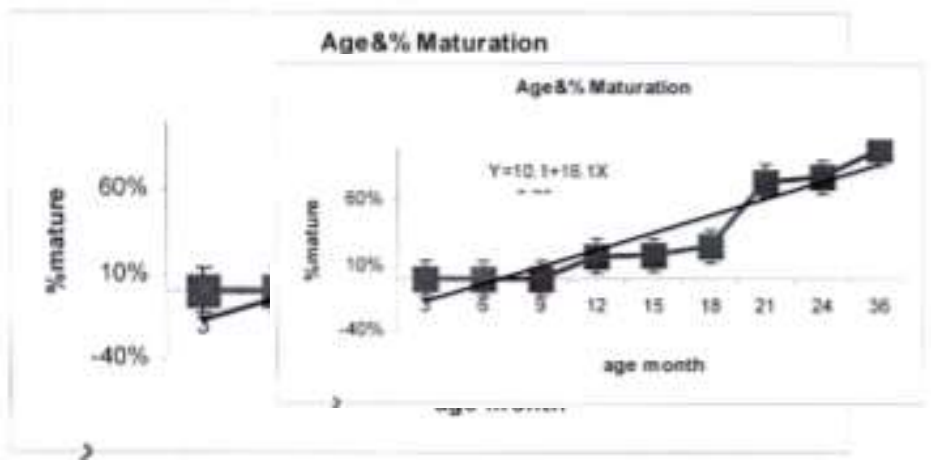


Fig. (3): The relations between percentage maturity and age (months)of gilthead sea bream, Sparus aurata

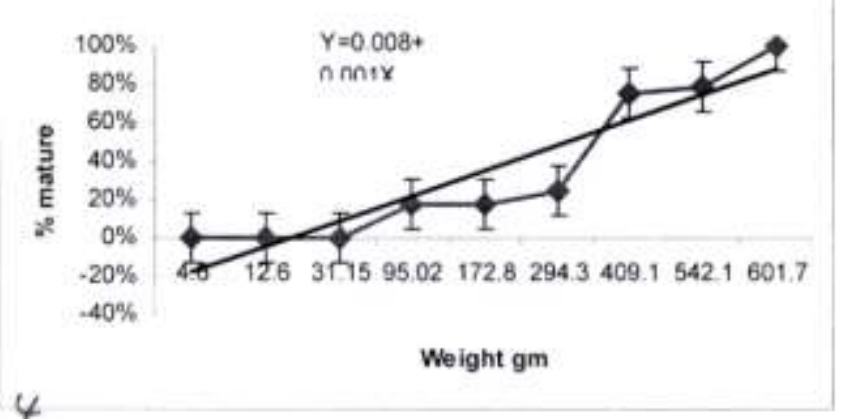

Fig. (4): The relation between weight(g)and maturity percentage of gilthead sea bream, Spams aurata

Results of Table 3 and Fig. 3 indicate that no maturation in both sexs of sea bream was observed during the ages 3; 6 and 9 months of age. At the age 12 months, $17.3 \%$ were mature (male and female), the relationship was highly significant $(\mathrm{P}<0.05)$.

At age 15, 18,21, 24, and 36 months of age, percent of mature male and females were found to be $18.2,25.0,75.0,79.0$, and $100 \%$, respectively. The correlation coefficient between age and maturation ( both sexes) was highly significant with a value of $r=0.75$ and the relationship between age and percent of male and female maturation is expressed in the following equation, $Y=10.1+16.1 X$, where $Y=$ age in month , and $X=\%$ of maturation

Result of Table 3 and Fig. 4 revealed that these were highly significant $(P<0.05)$ correlations $(r=0.72)$ between body weight, body length and percent of maturation in both male and female sea bream. The relation between body weight and percent of maturation is expressed as: $\mathrm{Y}=0.008+0.001 \mathrm{X}$, where $\mathrm{Y}=\%$ of maturation, and $\mathrm{X}=$ body weight in $\mathrm{g}$

Results (Table 3 and Fig. 5) revealed also that there was highly significant $(P<0.05)$ correlation $(r=0.75)$ between \% of maturation and body length of both sexs of sea bream. The relation between length and maturation is expressed in following equation $Y=-0.34+0.03 X$, where $Y=$ percent of maturation and $\mathrm{X}=$ length in $\mathrm{cm}$

As present in Table 3 and Fig. 6, results revealed that weight of sea bream correlated highly significant $(P<0.05)$ with a value of $r=0.94$ and the relationship between both is expressed as following : $Y-10.4+0.037 \mathrm{X}$, where $Y=$ is the fish length in $\mathrm{cm}$ and $X=$ is the fish weight in $\mathrm{g}$. 


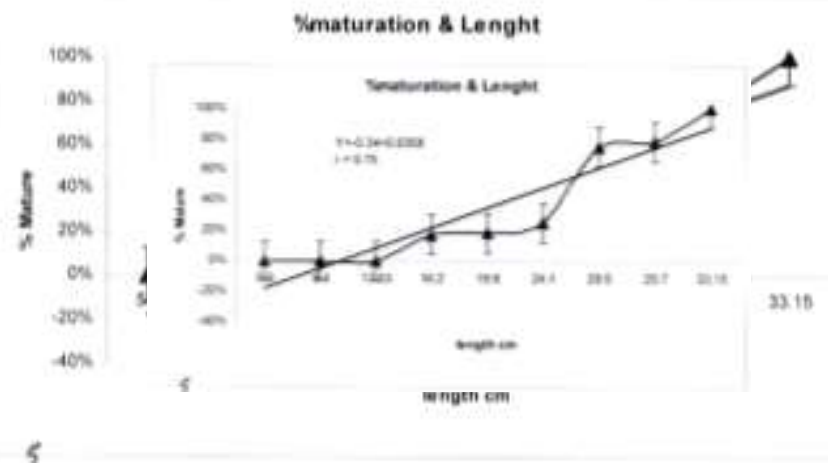

Fig. (5): The relation between length $(\mathrm{cm})$ and maturity percentage of gilthead sea bream, Spams aurata

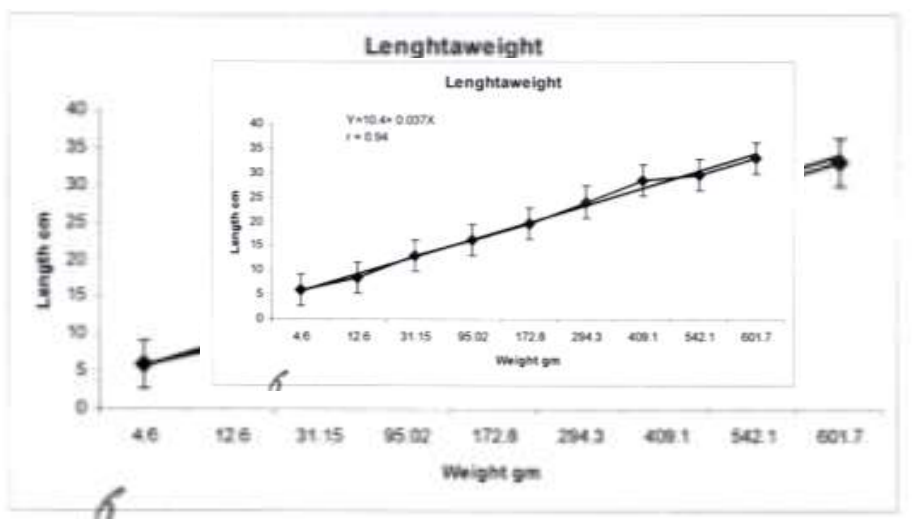

Fig. (6): The relation between weight $(\mathrm{g})$ and length $(\mathrm{cm})$ ol gilthead sea bream, Spams aurata during experimental period ( 3 years )

As presented in Table 4, results revealed that during the period from 3 to 9 months of age no maturation was observed in both female and male sea bream. At age of 12 months no maturation of female was detected, however at this age, $17.3 \%$ of the males in the sample show maturation with a length ranging from $14.9-16.2 \mathrm{~cm}$ and weight ranging from 73.1 to $92.2 \mathrm{~g}$. At 15 months of age, $18.2 \%$ of the brood stock showed maturation where $0.97 \%$ of the female were mature with an average length $22.4 \mathrm{~cm}$ and weight $267.8 \mathrm{~g}$ .At this age, 17.3 males in the sample showed maturation with an length and weight ranges between $17.7-18.9 \mathrm{~cm}$ and 127.7 to $152.6 \mathrm{~g}$., respectively. At 18 months of age, $25.3 \%$ of both sexes showed maturation where $4.7 \%$ of the female were mature with an average length 25.7 to $28.5 \mathrm{~cm}$ and weight391.4 to $415.3 \mathrm{~g}$.At this age, $20.6 \%$ males in the sample showed 
maturation with an length and weight ranges between 22.1 to $22.5 \mathrm{~cm}$ and 129.7 to $257 \mathrm{~g}$, respectively .

Table (4): Effect of age. weight and total length on percentage of gilthead sea bream, Sparus aurata maturation

\begin{tabular}{|c|c|c|c|c|c|c|c|c|c|}
\hline \multirow{2}{*}{$\begin{array}{l}\text { Age after hatch } \\
\text { (month) }\end{array}$} & \multirow{2}{*}{$\begin{array}{l}\text { Fish } \\
\text { No. }\end{array}$} & \multirow{2}{*}{$\begin{array}{c}\text { Total } \\
\text { length } \\
\mathbf{c m}\end{array}$} & \multirow{2}{*}{$\begin{array}{c}\text { Total } \\
\text { weight } \\
\mathrm{g}\end{array}$} & \multicolumn{2}{|c|}{$\begin{array}{c}\% \text { of mature } \\
\text { fish }\end{array}$} & \multicolumn{2}{|c|}{ Female } & \multicolumn{2}{|l|}{ Male } \\
\hline & & & & No. & $\%$ & No. & $\%$ & No. & $\%$ \\
\hline 3 & 106 & 5.9 & 4.6 & & 0 & - & 0 & - & 0 \\
\hline 6 & 156 & 8.4 & 12.6 & & 0 & - & 0 & - & 0 \\
\hline 9 & 112 & 13.05 & 31.15 & & 0 & - & 0 & - & 0 \\
\hline 12 & 75 & 16.2 & 95.045 & 13 & 17.3 & - & 0 & 13 & 17.3 \\
\hline Length range & - & - & - & - & - & - & - & 14.9-16.2 & - \\
\hline Weight range & - & - & - & - & - & - & - & $73.1-92.2$ & - \\
\hline 15 & 104 & 19.6 & 172.8 & 19 & 18.2 & 1 & 0.96 & 18 & - \\
\hline Length range & - & - & - & - & - & 22.4 & & $17.7-18.9$ & 17.3 \\
\hline Weight range & - & - & - & - & - & 267.8 & 4.7 & $127.7-152.6$ & - \\
\hline 18 & 63 & 24.1 & 294.3 & 16 & 25.3 & 3 & - & 13 & - \\
\hline Length range & - & - & - & - & - & $25.7-28.8$ & - & $22.1-22.5$ & - \\
\hline Weight range & - & - & - & - & - & 391.4-415.3 & - & $195.7-257$ & 20.6 \\
\hline 21 & 94 & 28.6 & 409.1 & 71 & 75.5 & 25 & 26.6 & 46 & 48.9 \\
\hline Length range & - & - & - & - & - & $28-32.8$ & - & $26.3-28.3$ & - \\
\hline Weight range & - & - & - & - & - & 339.9-698.7 & - & 289.1-434.5 & - \\
\hline 24 & 97 & 29.7 & 542.1 & 76 & 79.3 & 31 & 31.9 & 46 & 47.9 \\
\hline Length range & - & - & - & - & - & $29.9-35.2$ & - & $27.2-30$ & - \\
\hline Weight range & - & - & - & - & - & 541.1813 .5 & - & $332-587$ & - \\
\hline 36 & 112 & 33.15 & 601.7 & 112 & 100 & 47 & 41.9 & 65 & 58.02 \\
\hline Length range & - & - & - & - & - & $30.3-42.4$ & - & $29.5-34.6$ & - \\
\hline Weight range & - & - & - & - & - & $461.9-934.6$ & - & $340-669.4$ & - \\
\hline & & & & & & & & & \\
\hline
\end{tabular}

At 21 months of age, $75.5 \%$ of sample individuals showed maturation where females represented $26.6 \%$ and males $48.9 \%$ of the matured individuals. The length at females maturation was between 28 to $32.8 \mathrm{~cm}$ and the weight between 339.9 to $698.7 \mathrm{~g}$. The length of males mature was between 26.3 to $28.3 \mathrm{~cm}$ and the weight 289.1 to $434.5 \mathrm{~g}$.

At 24 months of age, percent of matured fish in the sample was $79.3 \%$ and female contributed fish in sample $31.9 \%$ and males by $47.4 \%$ (Table 4 ), the length from female between 29.9 to $35.2 \mathrm{~cm}$ and the weight between 541.1 to $813.5 \mathrm{~g}$, and length from male matured in this sample was 27.2 to 30 $\mathrm{cm}$ and weight was 332 to $587 \mathrm{~g}$. At 36 months of age $100 \%$ of the brood stock (males and females) were mature and matured females represented $41.9 \%$ of matured fish and matured males represented $58.02 \%$ of the sample. The ranges of body length and weight at 36 months were 30.3 to $42.4 \mathrm{~cm}$ and 461.9 to $934.6 \mathrm{~g}$ for female and 29.5 to $34.6 \mathrm{~cm}$ and 340 to $669.4 \mathrm{~g}$ for male, respectively. At the age of 36 months after hatch, all sea bream male and female fish reached $100 \%$ maturation with a sex ratio $1: 1.38$ for female and male, respectively.

In this connection Zaki et al., (1998) reported that at length group of sea bream $18.20 \mathrm{~cm}$, all fish were hermaphrodite, while in our study a male sea bream were detected at length group $14.9-16.2 \mathrm{~cm}$ and 12 months age. Also, Zaki et al., (1998) indicated that the sex ratio shifted to male at length group $21-21.9 \mathrm{~cm}$ and the percentages of female were $48,76.12$ and 83.35 
\% for length groups $21-21.9 \mathrm{~cm} ; 22-22.9 \mathrm{~cm}$ and $23-23.9 \mathrm{~cm}$., respectively. Results of tables $(4-5)$ are also in close to results of Zaki et al., (1998), Zohar et al., (1978) studied the gonadal development of Sparus aurata during the first year of life and concluded that entire gonads act as testis (males) at the second year of life then the sex changes to female from the end of that year.

In the same field, Carnevali et al., (1992) reported that Spaurs aurata is a hermaphrodite species since the male sex expressed on the second year of life and later changed into females which led to a numerical gradual depletion of males from the population. Also results of Table 5 are in partial agreement with the findings of Barnabé (1994), who stated that $100 \%$ of male and female of sea bream in nature reached maturity at $24 \mathrm{~cm}$. length. She added that first maturity was reached at $19-20 \mathrm{~cm}$. in males and $23 \mathrm{~cm}$. in females. The same author reported also that $S$. aurata became mature during second year of age.

It could be conclude that the complete sexual maturity of male and female occurred at 36 month of age .

Physico-chemical characteristics of experimental tanks water:

Results of Table (5) show the physico-chemical characteristcs of experimental tanks water during 36 successive months from May 2001 to December 2004.Water quality parameters including water temperature $\left({ }^{0} \mathrm{C}\right)$, dissolved oxygen (DO) , $\mathrm{pH}$, ammonia $\left(\mathrm{NH}_{3}-\mathrm{N}\right)$ and salinity $(\mathrm{ppt} \%$ ) were measured throughout the experiment. All water quality parameters were within the permissible levels for sea bass aquaculture. The chemical equilibrium between undissociated ammonia and total ammonia is a function of salinity, temperature and, to a large extent, $\mathrm{pH}$ (Miller et al., 1990; Soderberg and Meade, 1991; Boyd, 1990). For equal initial concentration values of total ammonia, a pH variation from 7 to 8 leads to a 10 -fold increase in the formation of the toxic fraction(Lloyd, 1992).

Table (5): Physical and chemical water parameters in experimental tanks(Mean values \pm SE)

\begin{tabular}{|l|c|c|c|}
\hline \multicolumn{1}{|c|}{ Parameters } & Minimum & Maximum & Mean \pm SE \\
\hline Water temperature $\left({ }^{0} \mathrm{C}\right)$ & 14.4 & 29.4 & $21.9 \pm 7.4$ \\
\hline Dissolved oxygen $(\mathrm{DO}, \mathrm{mg} / \mathrm{l})$ & 6.1 & 6.5 & $6.3 \pm 0.21$ \\
\hline $\mathrm{pH}$ & 7.4 & 8.0 & $7.7 \pm 0.30$ \\
\hline Ammonia $\left(\mathrm{NH}_{3}-\mathrm{N}, \mathrm{mg} / \mathrm{l}\right)$ & 0.033 & 0.061 & $0.047 \pm 0.014$ \\
\hline Salinity $(\% \circ)$ & 30.2 & 35.4 & $32.8 \pm 2.6$ \\
\hline
\end{tabular}

\section{REFERENCES}

Andrades, J.A., Becerra, J. and Fernandez-Llebrez, P, (1994). Skeletal deformities of the gilthead sea bream (Sparus aurata, L.): study of the subcommissural organ (SCO) and Reissner's fiber (RF). Ann. Anal., 176: 381-381.

AOAC (Association of Official Analytical Chemists) (1990): Official methods of 
analysis of the Association of Official Analysis Chemists. $15^{\text {th }}$ edition AOAc, Inc, Arlington. Virginia, U.S.A.

Barnabe, G. (1994) Aquaculture. Biology and Ecology of cultured species. Ellis Honvwod, New York. pp 64-86

Barnabe, G. (1990) .Rearing bass and gilthead bream. Aquaculture, 2 (ed G. Barnabe), Ellis Horwood. New York pp 64-86.

Boglione C.,De Marzi P., Spano A., Giganti M., Costa C. and Cataudella S.(2003).Morphological quality assessment of reared juveniles from Mediterranean aquaculture Experimental Ecology and Aquaculture Laboratory Biology Dept. Univer. of Rome.

Boyd, C. E. (1990). Water Quality in ponds for aquaculture. Agriculture Experiment Station, Auburn Univ, Alabama, U.S.A.482 pp.

Carnevali,O.,Mosconi,G.,Rocartari,A.,Belvedere,P.,Romano,M., and Dimitriou E. (2000). Results of intentional or sporadic releases of euryhaline fish species in coastal biotopes.Book of Abstracts. Research and Technology Forum, Zappio, 11-12 May 2000, pp 49-54.

Duncan,D. B (1995). Multiple range and multiple F- test. Biometrics, range (I):I-42.FAO(2006).FishStat.http://www.fao.org/fi /statist/FISOFT/FISHPLUS.asp

FEAP,(2009).Nationalaquacultureproduction.http://www.aquamedia.org/FileLi brary/11/Productionreport2008

Jobling. M. (1983). A short review and critique of methodology used in fish growth and nutrition studies. J. Fish Biology,23: 685 - 703.

Kirk, R. (1987). A History of Marine Fish Culture in Europe and North America. Fishing News Books, Oxford.

Lloyd, R., (1992). Pollution and Freshwater Fish. Fishing News Books, West Byfleet.

Miller, C.L., Poucher, S., Cardin, J.A.and Hansen, D., (1990). The acute and chronic toxicity of ammonia to marine fish and a mysid. Arch. Environ. Contam. Toxicol. 19, 40- 48.

NRC,(1993). Nutrient Requirement of Fish. Committee on Animal Nutrition. Board on Agriculture,National Research Council.National Acad. Press.Washington,D.C. 1993

Oliva-Teles A. (2000), Recent advances in European sea bass and gilthead sea bream nutrition. Aqua. Int. V. (8) 477-492

SAS (2005).Statistical Analysis System,SAS program,ver.9.1.SAS institute incorporation,Gary,NC27513 USA.

Soderberg, R.N.and Meade, J.W., (1991). The effects of ionic strength on unionized ammonia concentration. Prog.Fish-Cult. 53, 118-120.

Zaki, M.I.,Hagras,A.El-W.,El-Sayyad,H.E.,Assem,S.S., El-Gamal, Abd ElHakim.(1998).Studies on some biological parameters of the gilthcad bream Sparus aurata (L,) reared in fish farms. J. Egypy. Ger. Soc. Zool., 59-74.

Zohar, Y., (1989). Endocrinology and fish farming aspects in reproduction growth andsomoltification Fish Phys. Biochem., 7: 395-405.

Zoher, Y., (1991). The gilthead sea bream Sparus aurata, a model for the study of sex reversal and manipulation ofspawning on marine fish farming Unt. Symo. On. Reproductive Biology in Aqa Culture
Formatted: Font: (Default) Arial, $10 \mathrm{pt}$, Complex Script Font: Arial, 10 pt

Formatted: Font: (Default) Arial, $10 \mathrm{pt}$ Complex Script Font: Arial, $10 \mathrm{pt}$

Formatted: Font: (Default) Arial, $10 \mathrm{pt}$, Complex Script Font: Arial, 10 pt

Formatted: Font: (Default) Arial, $10 \mathrm{pt}$, Fon color: Auto, Complex Script Font: Arial, 10 pt

Formatted: Font: (Default) Arial, 10 pt, Fon color: Auto, Complex Script Font: Arial

Formatted: Font: (Default) Arial, $10 \mathrm{pt}$ Complex Script Font: Arial, 10 pt

Formatted: Font: (Default) Arial, $10 \mathrm{pt}$, Complex Script Font: Arial, 10 pt

Formatted: Font: (Default) Arial, $10 \mathrm{pt}$ Complex Script Font: Arial, 10 pt

Formatted: Font: (Default) Arial, $10 \mathrm{pt}$ Complex Script Font: Arial, 10 pt 
(Abstract) Taipie, Taiwan: 22-27 April.

Zohar Y., Abraham M. and Gordon H. (1978). The gonad cycle of the captivity-reared hermaphroditic teleost Sparus aurata during the fi rst two years of life. Ann. Biol.Biochem. Biophys., 18: 877-882.

Zohar, Y., Billard, R. and Weil. C. (1984). La reproduction de la daurade Sparus aurata et du bar Dicentrarchus labrax: connaissance du cycle sexual et control de lagametogencse et de la ponte. In L' Aquaclture du Bar des et sparidcs, pp.3-24. Edited by Barnabe and R. Billard. INRA, Paris.

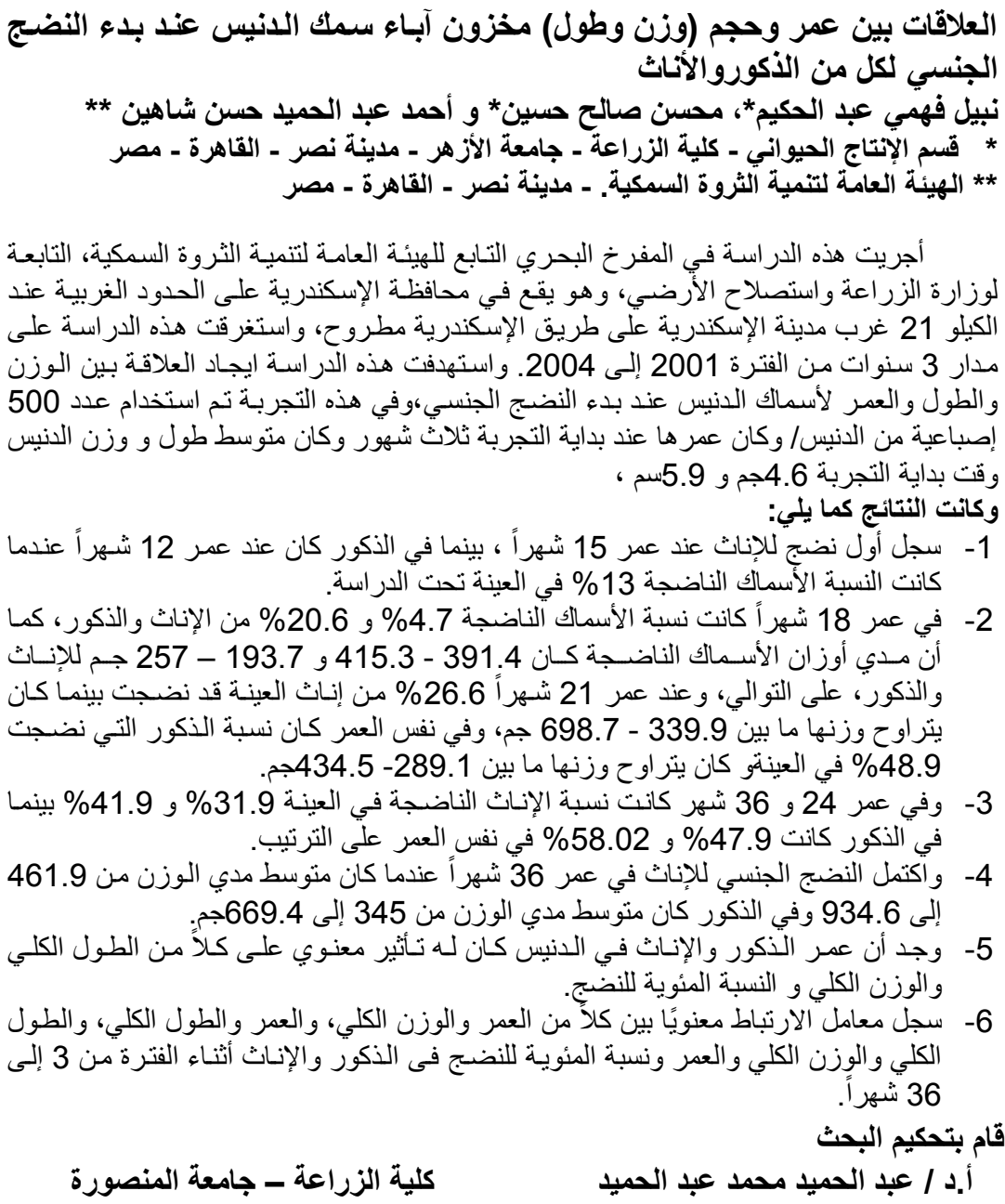

Formatted: Font: (Default) Arial, $10 \mathrm{pt}$ Complex Script Font: Arial, 10 pt

Formatted: Font: (Default) Arial, $10 \mathrm{pt}$, Fon color: Auto, Complex Script Font: Arial, 10 pt

Formatted: Font: (Default) Arial, $10 \mathrm{pt}$, Complex Script Font: Arial, $10 \mathrm{pt}$

Formatted: Font: (Default) Arial, $10 \mathrm{pt}$ Complex Script Font: Arial, 10 pt 
Abd El-Hakim, N. F. et al.

كلية الزراعة ـ جامعة قناة السويس

أ.د / عبد الحميد محمد صلاح عيد 